\title{
Floating of mud snails Hydrobia ulvae in tidal waters of the Wadden Sea, and its implications in distribution patterns
}

\author{
W. Armonies ${ }^{1} \&$ D. Hartke ${ }^{2}$ \\ ${ }^{1}$ Biologische Anstalt Helgoland, Wattenmeerstation Sylt; D-25992 List, Germany \\ ${ }^{2}$ Institut für Meereskunde; Troplowitzstr. 7, D-22529 Hamburg, Germany
}

\begin{abstract}
Juvenile mud snails Hydrobia ulvae disperse by floating at the water surface in summer. The routes of dispersal are determined by the hydrography of the specific area and can be successfully predicted by a hydrographic model. Along these routes, juveniles may aggregate in temporary "satellite" sites. Turnover of organisms was high at these sites. On average, an individual only stayed for 2 days in June and July, and a few hours in August. Consequently, abundance may vary by an order of magnitude within a few days. In August, the satellite sites were depopulated again, presumably due to behavioural changes. Because of the high mobility, caution is advised when including juvenile mud snails in descriptive or experimental field studies. High turnover rates of individuals in the sediment have also been recorded for juvenile bivalves and various meiofaunal taxa. The value of single-site sampling may therefore be questioned with respect to migrating benthic species. Instead, a mapping of resident and satellite subpopulations is recommended.
\end{abstract}

\section{INTRODUCTION}

Increasing evidence suggests that many benthic organisms living in shallow waters are highly mobile via the water column. According to the depth within the sediment, they are more or less susceptible to resuspension by tidal currents, particularly during stormy weather. But many benthic species may also enter the water column actively. Swimming may occur rather regularly in many crustaceans (e.g. harpacticoids: Walters, 1988; isopods: Jones \& Naylor, 1970; amphipods: Preece, 1971; cumaceans: Macquart-Moulin, 1991). In polychaetes, swimming seems to occur more episodically, since being restricted to certain seasons, e.g. winter migrations of Nereis virens (Dean, 1978), or phases of individual development, as in the lugworm Arenicola marina (Beukema et al., 1978; Farke \& Berghuis, 1979). In molluscs, byssus drift or floating of juveniles seems to be widespread (Williams \& Porter, 1971; Sigurdsson et al., 1976; Little \& Nix, 1976; Johannesson, 1988; Beukema \& de Vlas, 1989; Martel \& Chia, 1991).

Byssus-drift depends on both active behaviour of the organisms (excavating from deeper sediment layers to the surface, production of byssus-threads or a mucous float), and the existence of water currents lifting the specimens from the sediment surface and carrying them away. The active component allows the specimens to determine the timing of transport, while the direction of transport depends on the hydrography of the surround- 
ing area. Unpublished preliminary results suggest that current velocity influences settlement as well.

Migratory rhythms and the effects of migrations on distribution patterns were studied in detail in the most abundant mollusc species of the intertidal sandflats near the Island of Sylt in the northern Wadden Sea. In earlier papers, we described the temporal rhythms of migratory activity and the effects of migration on distribution patterns of Macoma balthica recruits (Armonies, 1992; Armonies \& Hellwig-Armonies, 1992). Therefore, we will now concentrate on the effects of migrations in mud snails Hydrobia ulvae.

In 1991, drifting mud snails were scarce before mid-June and floaters were then mainly year-old organisms (Armonies, 1992). From mid-June to the end of September, abundance of drifting mud snails was one to three orders of magnitude higher, and the floating specimens were mainly (98\%) juveniles with $<2 \mathrm{~mm}$ shell-length. Floating mud snails were more abundant in the water column during daylight than in the dark, but no further rhythm of migratory activity could be detected (Armonies, 1992). In 1992, the temporal pattern of floating mud snails was similar.

\section{MATERIALS AND METHODS}

The study was conducted in the Königshafen Wadden area near the Island of Sylt (North Sea, Fig. 1). A general description of the area and its biota is given in Reise (1985). Abundance patterns of Hydrobia ulvae in the sediment were studied at 22 sites of the southern Königshafen ("Oddewatt") intertidal flats in March, July/August, and September, 1991 (Fig. 1). Ten replicate sediment cores having a $10 \mathrm{~cm}^{2}$ cross-sectional area
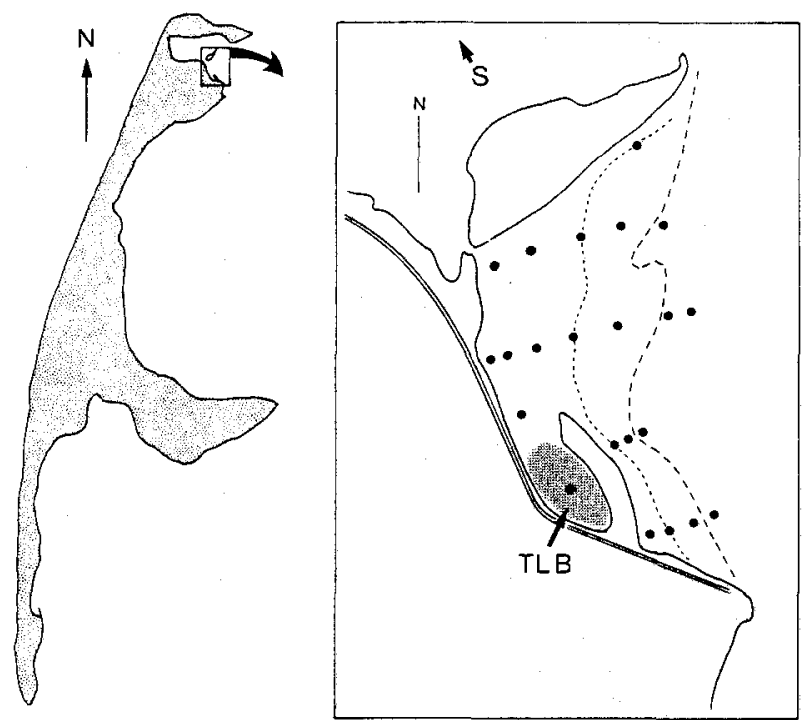

Fig. 1. Distribution of Hydrobia ulvae in Oddewatt near the Island of Sylt in March, 1991. Intensity of hatching indicates abundance (see Fig. 4). Broken line: mean low-tide level; dotted line: mean tidal level. Spots indicate sampling sites; S denotes the site where turnover was measured in 1992; TLB = 
and $5 \mathrm{~cm}$ depth were collected at each of the sites and on each of the dates. In the laboratory, specimens were separated from the bulk of the sediment using a shakingdecantation procedure (see Armonies \& Hellwig, 1986), with subsequent sieving of the decanted water through $0.25 \mathrm{~mm}$ meshes. The hydrographic plots (Fig. 3) are derived from a larger-scale numerical model developed by J. Backhaus and D. Hartke, University of Hamburg.

Abundance of $H$. ulvae in a temporary satellite site was studied in the Königshafen Wadden area, $200 \mathrm{~m}$ North of Oddewatt, between June 4th and August 31st, 1992 (Fig. 1. S). Ten replicate sediment cores were collected at weekly intervals, and evaluated as above, from a $10 \times 10 \mathrm{~m}$ plot in the mid intertidal. At the same site, a horizontal plankton

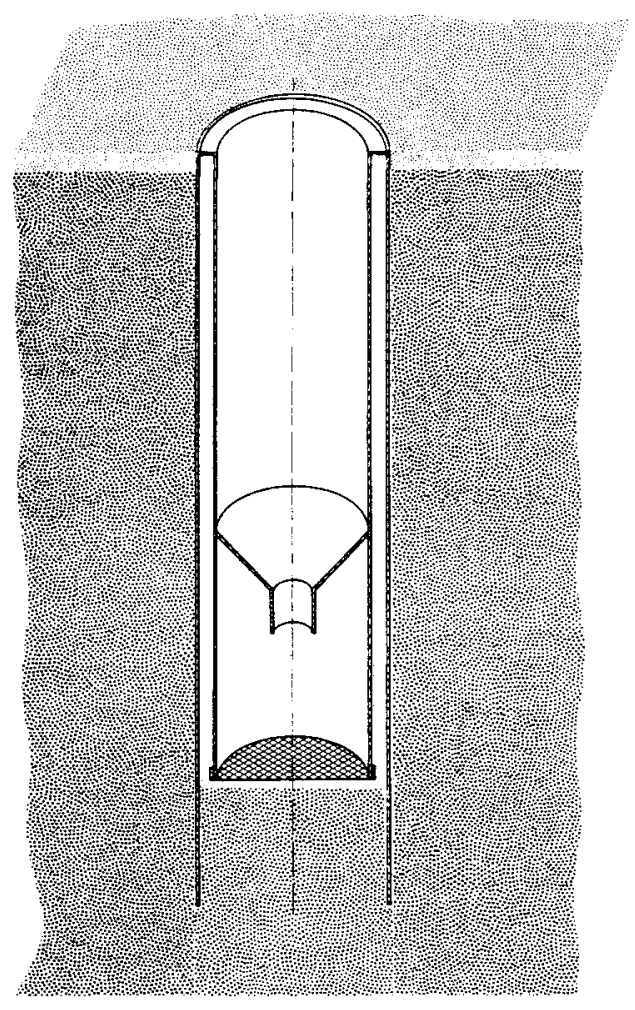

Fig. 2. Trap used to estimate the number of floaters sinking to the sediment. The trap consists of 2 concentric plastic pipes. The outer pipe $(15 \mathrm{~cm}$ diameter, $50 \mathrm{~cm}$ long) prevents collapse of the ambient sediment as the inner pipe (the trap s. str.) is removed. It protrudes above the sediment surface by about $2 \mathrm{~cm}$. The inner pipe $(35 \mathrm{~cm}$ long, $12 \mathrm{~cm}$ inner diameter) bears a plastic ring at its top end, tightly sealing both pipes. Once an individual is trapped in the inner pipe, a funnel reduces the chance for escape. At the lower end, the inner pipe is sealed by a removable lid made from a narrow plastic ring covered with gauze of $0.063 \mathrm{~mm}$ mesh. The wall of the inner pipe was pierced below the rim of the funnel to allow an escape of air when the tide comes in. These holes were covered by $0.063 \mathrm{~mm}$ gauze as well. The trap is emptied by removing the inner pipe, and opening the lower mesh cover. Both pipes were covered by a piece of wire mesh ( $5 \mathrm{~mm}$ mesh width) anchored in the sediment by pins (not indicated in Fig. 2). These meshes prevent the inner trap from floating and keep larger epifauna, such as shore crabs, out of the trap 
net (anchored at a vertical pipe) continuously recorded the number of drifting organisms passing the area. The net $(0.5 \mathrm{~mm}$ mesh width) adjusts itself to the direction of the currents (see Armonies, 1994, for a more detailed description). A trap sunk into the sediment (Fig. 2) was used to estimate the number of floaters returning to the sediment at this site. Both sediment traps and plankton nets were emptied and reset once a day.

Turnover was calculated as the ratio between the number of organisms caught per $\mathrm{m}^{2}$ of trap opening during one week, and the average abundance per $\mathrm{m}^{2}$ of ambient sediment (the mean abundance from sediment samples collected at the beginning and the end of the respective week). Turnover has thus the unit week ${ }^{-1}$, and its reciprocal gives the average length of time an individual stays at the same site.

\section{RESULTS}

\section{Winter distribution of mud snails}

In March 1991, the abundance of mud snails was $<500 \mathrm{~m}^{-2}$ at most of the sites. A higher abundance only occurred in two isolated patches: (1) at the northwestern border of Oddewatt $\left(4800 \mathrm{~m}^{-2}\right)$ in sandy sediment with a moderate silt content (about $2 \%$ of sediment dry weight), and (2) in a semi-enclosed bay "Tonnenlegerbucht" in muddy sediment $\left(52200 \mathrm{~m}^{-2}\right.$; TLB in Fig. 1). The same distribution pattern was observed in March/April, 1992.

\section{Direction of the tidal currents}

Since in winter and spring Hydrobia ulvae is only abundant in the upper intertidal, specimens can only be transported between about $2 \mathrm{~h}$ before high tide when the highdensity sites are flooded and, afterwards, with the ebbing waters. Since the flooding water mainly flows towards the land, efficient transportation out of the semi-enclosed bay may only occur with the ebbing waters. In these shallow waters, the direction of the ebb current is strongly modified by wind (Fig. 3). Northern wind increases the velocity of the tidal current without significantly changing its direction. Southern wind, however, may completely alter the direction of the ebbing water (Fig. 3). Intermittent wind directions show intermittent effects. Thus, starting from the high-density patch of mud snails in TLB (Fig. 1), there are two main routes of anticipated transportation. The northern route (of southern winds) leads longshore towards the second patch of mud snails observed in March. The southern route leads around the sandy hook, separating TLB from the lower intertidal and further south east towards the lower intertidal. Since only a few mud snails have been found buried in the sediment along the southern route in March $\left(<100 \mathrm{~m}^{-2}\right)$, this area is well-suited to test for the anticipated transportation of drifting mud snails (see below).

\section{Summer distribution of mud snails}

Distribution of Hydrobia ulvae in July/August reveals dispersion along both routes. Particularly high abundance occurred in a patch outside the sandy hook along the southern route $\left(>100000 \mathrm{~m}^{-2}\right.$; Fig. 4). Specimens within this patch consisted of $>95 \%$ 




Fig. 3. Direction of the tidal currents in Oddewatt, $1 \mathrm{~h}$ after high tide, assuming no wind, and southern and northern winds of $9 \mathrm{~m} / \mathrm{s}$. Current velocity increases with arrow complexity

juveniles with $<2 \mathrm{~mm}$ shell length, whereas the presumed original population in TLB consisted of 80 to $90 \%$ adults having $>2 \mathrm{~mm}$ length simultaneously. Thus, it seems the young left the densely populated TLB site and dispersed with the ebbing water both in a southerly and a northerly direction (Fig. 4). However, dispersal along both routes did not result in a continuous enlargement of the occupied area. Until September, abundance dropped by one order of magnitude at the newly-occupied upper intertidal sites, and the high-density patch in southern Oddewatt disappeared almost completely $\left(<1000 \mathrm{~m}^{-2}\right.$ left).

\section{High turnover in temporary satellite sites}

Abundance of $H$. ulvae in the sediment was low $\left(<1000 \mathrm{~m}^{-2}\right)$, until drifting juveniles arrived in mid-June, 1992; then abundance increased to $>100000 \mathrm{~m}^{-2}$ within two weeks (Fig. 5A). At the end of July, abundance decreased again to the early-June level. Throughout the period studied, the daily number of organisms collected by the traps sunk into the sediment was of the same order of magnitude as abundance estimates from the ambient sediment (Fig. 5A). On average, individuals may have stayed at this site for about 2 days in June and July and possibly only for a few hours in August (Fig. 5D). 




Fig. 4. Distribution of Hydrobia ulvae in Oddewatt near the Island of Sylt in July/August and in September, 1991. Explanations as in Fig. 1

Abundance of floaters passing this site decreased by about one order of magnitude in August (Fig. 5B). This would have caused the similar decrease in the number of organisms collected by the sediment traps (Fig. 5A). However, behaviour of the floating mud snails also changed. The ratio between the number of $H$. ulvae simultaneously caught by the traps and plankton nets significantly decreased over time (Fig. 5C), indicating a decreasing proportion of the floaters sinking to the sediment. At the same time, turnover rates of the specimens in the sediment greatly increased (Fig. 5D). Thus, the depopulation of the satellite sites in August may be due to a combination of 3 factors: (1) an overall decrease in floater abundance; (2) a decrease in the percentage of floaters sinking to the sediment; and (3) a decrease in the period of time individuals stay at the site.

Fig. 5. Dynamics of Hydrobia ulvae juveniles in a temporary satellite site in summer, 1992. A: Abundance in the sediment (broken line) and daily number of colonizers to the sediment (trap) per $\mathrm{m}^{2}$ of surface area. $B$ : Abundance of floaters in the water column (individuals per net of $20 \mathrm{~cm}$ diameter per day; distance of the centre of the net from the sediment was $20 \mathrm{~cm}$ ). C: Proportion of floaters sinking to the sediment estimated as the ratio between the numbers of colonizers (trap), and simultaneously floating specimens (net). The decreasing trend (Spearman's rank correlation coefficient, $\mathrm{I}=-0.875, \mathrm{p}<0.001$ ) indicates a behavioural change over time. $D$ : Turnover per week 




\section{DISCUSSION AND CONCLUSIONS}

The age structure found in the temporary high-density area in southern Oddewatt ( $>95 \%$ juveniles $<2 \mathrm{~mm}$ length) is nearly identical to the distribution of size classes in floating mud snails as recorded by continuous plankton net records (97-98\% juveniles $<2 \mathrm{~mm}$ length: Armonies, 1992, Little \& Nix, 1976). This, and the high turnover rates, corroborate the hypothesis that the specimens in the temporary satellite sites indeed arrived by floating, and not as larvae. The low percentage of juveniles in TLB and the direct connection between TLB and the satellites by the tidal currents further confirm this assumption. Obviously, floating juveniles, not planktonic larvae, are the main stages of dispersal in Hydrobia ulvae. This may explain the short duration of the planktonic larval phase (Thorson, 1946).

On the other hand, abundance of mud snails in the densely populated TLB area remained remarkably stable throughout this study (March, 1991: $52200 \mathrm{~m}^{-2}$; July/ August: $59300 \mathrm{~m}^{-2}$; September: $57600 \mathrm{~m}^{-2}$; March, 1992: $64400 \mathrm{~m}^{-2}$ ). It may be speculated that this is the carrying capacity of this area, and emigration is densitydependent, as with Hydrobia ventrosa (Levinton, 1979). An alternative would be an age/ size-dependent shift in the mode of feeding. Juveniles may preferentially scrape epigrowth from sand grains (epipsammic browsing: Lopez \& Kofoed, 1980), while adults ingest individual mobile diatoms or swallow mud particles with the associated microflora (Fenchel \& Kofoed, 1976; Lopez \& Levinton, 1978). In this case, juveniles might find suitable habitats in seaward sandy flats which are not accessible to adults (e.g. Reise, 1987). A presumed shift in the preferred diet could also explain why the juveniles stay for shorter periods at the satellite sites, while they grow. However, floating mud snails may also gain a part of their food whilst afloat, by ingesting their mucous float with adhering particles (Newell, 1962).

As a result of frequent migrations, the distribution patterns of juvenile mud snails are highly variable over time. This should be taken into account in both descriptive and experimental field studies. Since the direction of transportation partly depends on actual wind conditions, short-term transportation directions cannot be properly calculated a priori. Without a map of adult distribution and a hydrographic model, estimation of transportation rates is not even possible a posteriori. In such cases, it is suggested that one avoid using juvenile Hydrobia ulvae as an experimental species or a monitoring tool (as indeed decided by Beukema, 1991). However, since other species, such as juvenile bivalves, show a similarly high degree of mobility, avoidance of a (still increasing) number of species is certainly not an advisable strategy to cope with unexpected mobility. Concerning migrations of some meiofaunal taxa in the same area, large-scale spatial sampling and/or several replications in time were suggested to overcome the difficulties involved with the mobility of species (Armonies, 1990). The same strategy may be useful in macrofaunal studies. A hydrographic model of the area studied is a valuable tool in order to determine the area which needs to be sampled.

Acknowledgements. Thanks are due to A. Barkow, H. Beushausen, H. Bock, A. Brodowski, A. Diederichs, W. Gaul, S. Gerbersdorf, P. Gienapp, J. Hanke, I. Mackensen, S. Menzel, U. Möhle, B. Saur, D. Teuber and S. Zacker, who were all busy changing plankton nets during low tide, emptying traps, and sorting millions of mud snails from thousands of samples. M. Hellwig-Armonies and K. Reise provided valuable comments throughout the study. This study was funded by the Federal 
Ministry of Research and Technology, and is contribution No. 115 of the project "Ecosystem Research Wadden Sea".

\section{LITERATURE CITED}

Armonies, W., 1990. Short-term changes of meiofaunal abundance in intertidal sediments. Helgoländer Meeresunters. 44, 375-386.

Armonies, W., 1992. Migratory rhythms of drifting juvenile molluscs in tidal waters of the Wadden Sea. - Mar. Ecol. Prog. Ser. 83, 197-206.

Armonies, W, 1994. Drifting meio- and macrobenthic invertebrates on tidal flats in Königshafen: a review. - Helgoländer Meeresunters. 48, 299-318.

Armonies, W. \& Hellwig, M., 1986. Quantitative extraction of living meiofauna from marine and brackish muddy sediments. - Mar. Ecol. Prog. Ser. 29, 37-43.

Armonies, W. \& Hellwig-Armonies, M., 1992. Passive settlement of Macoma balthica spat on tidal flats of the Wadden Sea and subsequent migrations of thread-drifting juveniles. - Neth. J. Sea Res. 29, 371-378.

Beukema, J. J., 1991. Changes in composition of bottom fauna of a tidal-flat area during a period of eutrophication. - Mar. Biol. 111, 293-301.

Beukema, J. J. \& Vlas, J. de, 1989. Tidal-current transport of thread-drifting postlarval juveniles of the bivalve Macoma balthica from the Wadden Sea to the North Sea. - Mar. Ecol. Prog. Ser. 52, 193-200.

Beukema, J. J., Bruin, W. de \& Jansen, J. J. M., 1978. Biomass and species richness of the macrobenthic animals living on the tidal flats of the Dutch Wadden Sea: long-term changes during a period with mild winters. - Neth. J. Sea Res. 12, 58-87.

Dean, D., 1978. Migration of the sandworm Nereis virens during winter nights. - Mar. Biol. 45, $165-173$.

Farke, H. \& Berghuis, E. M., 1979. Spawning, larval development and migration of Arenicola marina under field conditions in the western Wadden Sea. - Neth. J. Sea Res. 13, 529-535.

Fenchel, T. \& Kofoed, L. H., 1976. Evidence for exploitative interspecific competition in mud snails (Hydrobiidae). - Oikos 27, 267-376.

Johannesson, K., 1988. The paradox of Rockall: why is a brooding gastropod (Littorina saxatilis) more widespread than one having a planktonic larval dispersal stage (L. littorea)? - Mar. Biol. 99, $507-513$.

Jones, D. A. \& Naylor, E., 1980. The swimming rhythm of the sand beach isopod Eurydice pulchra. J. exp. mar. Biol. Ecol. 4, 188-199.

Levinton, J. S., 1979. The effects of density on deposit-feeding populations: movement, feeding and floating of Hydrobia ventrosa Montagu (Gastropoda, Prosobranchia). - Oecologia 43, 27-39.

Little, C. \& Nix, W., 1976. The burrowing and floating behaviour of the gastropod Hydrobia ulvae. Estuar. coast. mar. Sci. 4, 537-544.

Lopez, G. R. \& Kofoed, L. H., 1980. Epipsammic browsing and deposit-feeding in mudsnails (Hydrobiidae). - J. mar. Res. 38, 585-599.

Lopez, G. R. \& Levinton, J. S., 1978. Availability of micro-organisms attached to sediment particles as food for Hydrobia ventrosa Montagu (Gastropoda: Prosobranchia). - Oecologia 32, 263-275.

Macquart-Moulin, C., 1991. La phase pélagique des Cumaces. - J. Plankton Res. 13, 313-337.

Martel, A. \& Chia, F.-S., 1991. Drifting and dispersal of small bivalves and gastropods with direct development. - J. exp. mar. Biol. Ecol. 150, 131-147.

Newell, R., 1962. Behavioural aspects of the ecology of Peringia (= Hydrobia) ulvae (Pennant) (Gastropoda, Prosobranchia). - Proc. zool. Soc. Lond. 138, 49-75.

Preece, G. S, 1971. The swimming rhythm of Bathyporeia pilosa (Crustacea: Amphipoda). - J. mar. biol. Ass. U. K. 51, 777-791.

Reise, K., 1985. Tidal flat ecology. Springer, Berlin, $191 \mathrm{pp}$.

Reise, K., 1987. Distribution and abundance of small and juvenile macrofauna on the tidal flats in the Frisian Wadden Sea. - Biol. Meddr 31,7-25.

Sigurdsson, J. B., Titman, C. W. \& Davies, P. A., 1976. The dispersal of young post-larval bivalve molluscs by byssus threads. - Nature, Lond. 262, 386-387. 
Thorson, G., 1946. Reproduction and larval development of Danish marine bottom invertebrates, with special reference to the planktonic larvae in the Sound (Øresund). - Meddr Kommn Danm. Fisk.-og Havunders. (Plankton) 4, 1-523.

Walters, K., 1988. Diel vertical migration of sediment-associated meiofauna in subtropical sand and seagrass habitats. - J. exp. mar. Biol. Ecol. 117, 169-186.

Williams, A. B. \& Porter, H. J., 1971. A ten-year study of meroplankton in North Carolina estuaries: occurrence of postmetamorphal bivalves. - Chesapeake Sci. 12, 26-32. 